\title{
Evaluation of Cashless Policy in Nigeria: The Pros and Cons
}

\author{
Stephen O. Maitanmi ${ }^{1^{*}}$, Adetunji O. ${ }^{2}$ \& Joshua, A. A. ${ }^{3}$ \\ ${ }^{1 \& 2}$ Department of Software Engineering, Babcock University, Ogun State, Nigeria \\ ${ }^{3}$ Department of Accounting, Mountain Top University, Ogun State, Nigeria \\ maitanmio@babcock.edu.ng, adetunjio@babcock.edu.ng, babatunde.abimbola@yahoo.com
}

\begin{abstract}
The essence of this paper is to evaluate the practice of cashless policy that was introduced almost a decade ago in Nigeria. It was discovered through literature that the security threats of ATM users and the inappropriate use of POS are at an alarming rate. The paper used a structured questionnaire to collect data and the data were analyzed using descriptive statistics with the use of mean, median, and percentage. The results indicate that the awareness level is almost globally known, however; there are still more technological devices and development that are needed for Nigerians to be considered among the top 20 economies to drive the development and modernization of her payment system in line with the global vision. Based on the findings, some recommendations made were: POS should be approved only for the unbanked areas, panic alert buttons should be included in the ATMs, and comprehensive insurance should be available for ATM cash hijackers.
\end{abstract}

Keywords: Automated Teller Machine (ATM), Cashless Economy, Hijack, Point of Sales (POS), Tax

\section{Introduction}

Historically, we read and we were taught about the concept of a trade by barter. Trade by barter is still very much in practice as opposed to the idea that it is a pre-colonial idea where the Europeans traded with Africans from the coast (Ashike, 2020). What would you say to a colleague who released his car to be used for a few days all because I proofread his paper and other similar examples that may cut across your mind as you read this? Shortly, while the trade by barter is ongoing, money was introduced. Money is nothing if unacceptable as a medium of exchange and services. It can be a shell, a coin, or a piece of paper which have potential values. Money allows the exchange of services which is where it derives its value. At the secondary school levels, we learned further that money is a unit of measurement and a storehouse for wealth. Money is valuable because it is generally accepted by all as a medium of exchange. The emergence of a cashless policy which includes Internet banking, mobile banking, automated teller machine (ATM) came up as a development that enhances the reduction of physical cash as the emergence of information.

Technology has turned banking activities to paperless as it brought socioeconomic development and growth into the nation (Agu, \& Agu, 2020). Therefore, the implementation of a cashless policy was started by the CBN in 2012 to ensure that Nigeria is one of the best economies in the world by going cashless. From this implementation, it is expected to know by evaluation how the country fears the use of the policy and how is this helping to place the country at the forefront of the cashless policy. Therefore, the specific objectives are to evaluate the benefits of the cashless policy as established almost a decade ago in Nigeria and to know the prevailing challenges. Looking at the progress achieved, it is evidenced according to Iwedi, Igbanibo, \& Uzo-ahunanya, (2018) that there has not been any substantive achievement recorded since the tenure of the last Central Bank Governor (CBN) Lamido Sanusi Lamido. However, in 2017, he made a substantial move to attract charges to the high cost associated with the volume of cash handling along the value chain from the CBN and bank of operations and traders as seen in table 1. 
Table 1: Penalties Attached to Large Withdrawal of Cash

\begin{tabular}{cccc}
\hline \multirow{3}{*}{ Individual } & Amount & Deposit & Withdrawal \\
\cline { 2 - 4 } & Less than \#500,000 & Free of Charge & Free of Charge \\
& $\# 500,000-\# 1,000,000$ & $1.5 \%$ & $2 \%$ \\
& $\# 1,000,000-\# 5,000,000$ & $2 \%$ & $3 \%$ \\
Above $\# 5,000,000$ & $3 \%$ & $7.5 \%$ \\
Corporate & $\# 3,000,000-\# 10,000,000$ & $2 \%$ & $5 \%$ \\
& $\# 10,000,000-\# 40,000,000$ & $3 \%$ & $7.5 \%$ \\
& Above $\# 40,000,000$ & $5 \%$ & $10 \%$ \\
\hline
\end{tabular}

Source: (CBN, 2021).

\section{Literature Review}

The cashless policy which is a common trend globally was introduced by the Central Bank of Nigeria in 2012 to reduce excesses of handling cash in the society. A cashless society is a situation where a transaction takes place without the movement of physical cash thereby reducing cash transaction to the barest minimum as mentioned by (Ezuwore-Obodoekwe, Eyisi, Emengini, \& Chukwubuzo, 2014; Omotunde, Sunday, \& John-Dewole, 2013). However, before the emergence of cashless and paper money, different forms of means of exchange were in existence which includes gold, commodity money, legal tender money, and near money assets (Obafemi, \& Araoye, 2020). It is a society where transactions are carried out without the need for cash movement as a means of exchange. Similarly, it is done by electronic platforms such as the use of Automatic Teller Machine (ATM) available at various bank areas where cash can be withdrawn at intervals. Other platforms that support the cashless policy include; Point of Sale (POS)-terminals which are developed for merchant locations or unbank areas that enable users to swipe their electronic cards to make payment for purchases or services, NEFT-is an online platform where the money is being transferred between an individual or multiple beneficiaries, Real Time Gross Settlement (RTGS)-deals with the transfer of money in favor of a single beneficiary which is faster than cheque, e-transfer is an electronic transfer via the mobile devices using the Internet as the architecture, E-wallets are another method of electronic payment that store card numbers and cash. It is a virtual wallet that can store credit cards, debit cards, and other information electronically. An example of an E-wallet is PayPal. Mobile Wallet is also used in place of holding cash which is downloadable through mobile wallet application (app).

However, users do not need a credit card, debit card, or Internet banking password for making such transactions. It involves transferring money via IMPS which can be useful anywhere. A credit card is a digitized security card printed by financial institutions and configured for individual users which are used as a means of payment for goods and services. A credit card is the replicant of the holder's account (saving or current). A debit card is a new form of transaction in Nigeria where the cardholder can spend as much as their net pay. Therefore, electronic banking forms the major bedrock of a cashless society (Ikpefan, Enobong, Osuma, Evbuomwan, \& Ndigwe, 2018; Wali, Wright, \& Reynolds, 2014). Before the advent of the CBN cashless policy in Nigeria as of 2012, the business activities in Nigeria were carried out in cash to the tune of over 90\% (Wali, Wright, \& Reynolds, 2014). The CBN cashless policy is more evident and grounded in aiming at modernization of payment system, provision of more efficient transaction options to enhance financial inclusion, increase convenience, and reduction of cash-related crimes in the country. In January 2012, the Central Bank of Nigeria placed the daily limit of individual cash withdrawal and deposit to N150, 000 and that of corporate entity to N1,000,000 any deposit or withdrawal above this limit attracts the processing cost of $10 \%$ for individual and $20 \%$ for corporate entities. However, in June 2012, the policy was watered down to the limit of $\mathrm{N} 500,000$ for individual and N3,000,000 for corporate with the processing cost of $2 \%$ and $3 \%$ respectively with the main aim of reducing physical cash in the circulation and not total eradication as the beliefs of some authors [8] as represented in table 2 . 
Table 2: Showing Limited Withdrawal of Cash

\begin{tabular}{lllll}
\hline Year & \multicolumn{1}{c}{ Jan 2012 } & \multicolumn{1}{c}{ June 2012 } \\
\hline \multirow{2}{*}{ Limit withdrawal } & Individual & Corporate & Individual & Corporate \\
Processing cost & $\mathrm{N} 150,000$ & $\mathrm{~N} 1,000,000$ & $\mathrm{~N} 500,000$ & $\mathrm{~N} 3,000,000$ \\
\hline
\end{tabular}

The cashless policy initially took effect in Lagos, however, in 2017, the policy extended to the rest of the states of the federation and focused on turning Nigeria from a cash-based economy into an electronic-based economy whereby all transactions were on an electronic payment system to enable Nigeria monetary system to align with the international best practices. This will eventually enhance the proficiency of the Nigerian payment system aiming at achieving the overall quality of the banking system in Nigeria. Also, the negativity attached to handling physical cash such as high subsidy, high cost of cash, inefficiency, and corruption among others will be reduced to the barest minimum (Taiwo, Oluwafemi, \& Agwu, 2016; Adu, 2016). Other benefits associated with the cashless policy are the development and mineralization of the payment system by reducing the cost of banking services through the provision of a more effective transaction and also serve as means of eradicating inflation and boosting economic growth. However, one of the objectives of instituting the cashless policy in Nigeria by the (CBN) was to fully modernize the payment system in line with the Nigerian vision of being among the top 20 economics to drive development and modernization of her payment system in line with the global practices in the year 2020 (Iwedi, Igbanibo, \& Uzo-ahunanya, 2018).

Even though we are far beyond 2020, the goal is still unreachable. Some of the factors that may have hindered the achievements are lack of proper education which result from bad network connectivity that can enable multiple debiting on a spot and the issue of security had led many to still fall back to cash while transacting (Ikpefan, Enobong, Osuma, Evbuomwan, \& Ndigwe, 2018; Kasie \& Nwaolisa, 2012). Therefore, there is still so much concern regarding its implementation in Nigeria especially with respect to security issues which was visited in the next paragraph. Although, the cash-based society had been characterized by a number of negative factors such as robbery, kidnapping for ransom, the outrageous cost of currency printing and minting, corruption, currency leakages among others- Central Bank of Nigeria (CBN) (Wali, Wright, \& Reynolds 2014), (Adewale, 2013) \& (CBN, 2020). Similarly, the study of Akhalumeh and Ohiokah, (2011) stated some problems with the use of cashless policy which include the existence of Internet fraud, inadequate availability of e-payment or e-transaction platform, high level of illiteracy among others. The privacy of digital transactions is not $100 \%$ guaranteed as transactions are tied to a particular identity which might end up in malicious hands, unlike the cash-based society where cash can be received anonymously (Pritchard, 2020).

More so, except if CBN and other financial organizations concern should make special outreach efforts where the poor, homeless, and unbanked will experience fewer challenges in a cashless society especially if smartphones become the standard way to transact because they do not have the ways and means to procure a smart device (Noone, 2018). Therefore, to enhance the successful implementation of a cashless society in Nigeria, the issue of infrastructure, adequate security, and vulnerability of cash to all sorts of Internet crimes must be adequately attended to. The CBN must consider the level of literacy of the populace before the implementation of a cashless society in Nigeria and the level of infrastructure for a successful electronic transaction. The electronic system of transacting has been seen to be of great impact on the cashless policy as it will help the actualization of the vision of the Central Bank of Nigeria (Omotunde, Sunday, \& John-Dewole, 2013), (Ikpefan, Enobong, Osuma, Evbuomwan, \& Ndigwe, 2018), (Wali, Wright, \& Reynolds, 2014). Electronic banking is a means of transferring funds with the use of the Internet and computer as iterated earlier, so there is a need for the CBN to work in collaboration with the Deposit money banks and Telecommunication companies Wali, Wright, \& Reynolds, 2014).

Having seen the benefits of a cashless economy extensively as mentioned and most of the challenges have been handled by financial institutions. However, some setbacks have not been able to get attention from various solution providers of either Information Technology (IT) or banking experts. The first of this is transforming the POS into a business of cash withdrawal points against payment for goods and services even though these areas are bank areas. Similarly, the security threats that ATM users have suffered as a result of maintaining the cashless economy are overwhelming. Most of the holders are robbed at gunpoint and forced to the nearest outlet where they are asked to enter their identification number (PIN). Although, there is a myth that has never been proven 
'that users should reverse their codes and such sends security alert'. Obviously, this may be possible in developed countries where security agencies are at alert to solving problems, not in developing countries where agencies form a coalition to rub innocent citizens. Other challenges that have been addressed but still prevailed in cashless societies are the poor network that has consistently caused illegal deductions, and high transaction charges by banks. Therefore, the objective of this paper is to find out among the frequent users of ATM, POS, and other technologies associated with the use of a cashless economy whether these aforementioned challenges are existing. If they do, the paper aimed to proffer a lasting solution.

\section{Methodology}

Evaluation of cashless policy in Nigeria for its pros and cons were measured using the quantitative methods. This method employed the use of descriptive analysis which involved mean, median, mode, and percentage to compare the results to previous researches to evaluate the status of Nigeria concerning cashless policy. Seventy (70) users were randomly selected in South-West, Nigeria, where Lagos, Ibadan, Osogbo, and Akure were considered to participate in the quantitative research. Only fifty-two successfully returned their questionnaire. It is expected that all those who have bank accounts with other facilities such as ATM and POS be considered while those who don't have these experiences should not be included as participants.

Instrumentation: A research instrument was adopted with two constructs; awareness and security measures on the use of ATM and POS in a cashless economy. 1. The second section of the instrument after the demographic data was named 'awareness of cashless economy and this was measured using the Yes/No since this was testing for the knowledge of users. Yes means 1 while No means 0 as coded in the Statistical Package for Social Scientist (SPSS). 2. Similarly, the second construct was titled 'security of the use of ATM and POS'. This was measured using five Likert scale namely; strongly agree (1), agree (2), neutral (3), disagree (4), and strongly disagree (5).

The Validity and Reliability of the Instrument: The questionnaire was carefully developed to ensure that it covers the constructs and contents needed to measure the awareness and security level of ATM and POS. The instrument was scrutinized by researchers and other experts in the fields of computing, and financial institutions. Corrections were made to ensure the face and content validity of the instrument matches with the intention. The reliability of the instrument was achieved by administering the questionnaire to five (5) users in Benin City in the Edo State of Nigeria to establish the reliability of the instrument. The data collected was used to estimate the reliability of the instrument using Cronbach Alpha to bring out the internal consistency and construct reliability of the instrument. It was found to be 0.795 for the awareness and 0.845 for the security of ATM and POS.

Method of Data Analysis: The questionnaire was administered randomly and fifty-two (52) respondents were captured. The questionnaire was screened for outliers and missing values. This was further coded and analyzed using the Statistical Package for Social Sciences (SPSS) version 21. Descriptive statistics were used to determine the mean, median, mode, and percentage of the awareness and security of the ATM and POS.

\section{Results and Discussion}

From the demographics section of the instrument, Table 3 indicates that 30 males and 22 females responded to the questionnaire which is equivalents to $57.7 / 42.3 \%$ respectively. This shows an unbiased sex distribution. Similarly, it is evidenced from the table that the frequent users of the ATM and POS are within the working-class age of 18-57. Between 18-37, there were $42(80.8 \%)$ and 38-57, 10 (19.2) were discovered. It can therefore be concluded from this analysis that the active users are youth within the ages of $18-57$ which is influenced by educational status; those in the tertiary level were noticed to be more active where 40 participants were recorded to be involved with $76.9 \%$. Meanwhile, it appears that the awareness level of a cashless economy is no longer an issue in Nigeria. Table 3 shows that 40 respondents indicated interest that they are well aware of the existence of a cashless economy with $76.9 \%$ while only 6 respondents with $11.5 \%$ within the ages of $18-57$ showed that they are not aware of the practice of cashless economy. There is a significant increase in the awareness of cashless policy as reported in Maitanmi, Awodele, Ogbonna and Osundina, (2013) previously.

One can also judge by this data that the country is not doing too bad in fast-tracking the Nigerian economy to be among the first 20 world economist come 2020 and beyond that would drive development and modernization of 
our payment system in line with the Nigerian vision as claimed by Iwedi, Igbanibo, and Uzo-ahunanya (2018) and further supported by the research of John, Emmanuel, Ikechi, and Eke (2020), though there are still several challenges militating against that such as the COVID-19 pandemic issue and other related factors which is a global phenomenon. Also, revenue collection has been improved as supported by Bosupeng (2017) who claimed that the government found the cashless economy lucrative because it facilitates taxation which raises tax revenue. There were other insinuations about a cashless economy/policy being too expensive or that it prevents savings. Table 3 shows clearly that these are not valid statements. With respect to savings, the table shows that 52 respondents with $100 \%$ disagree that the cashless economy prevents savings. On the other hand, 44 respondents with $85 \%$ agreed that a cashless economy is not expensive with respect to the security of the liquid (money).

Table 3: Awareness of Cashless Economy

\begin{tabular}{lll}
\hline Gender & Number & Percentages \\
\hline Male & 30 & 57.7 \\
Female & 22 & 42.3 \\
Total & $\mathbf{5 2}$ & $\mathbf{1 0 0}$ \\
& & \\
Age & Number & Percentages \\
$18-37$ & 42 & 80.8 \\
$38-57$ & 10 & 19.2 \\
Total & $\mathbf{5 2}$ & $\mathbf{1 0 0}$ \\
& & \\
Educational & Number & Percentages \\
Primary & 12 & 23.1 \\
Tertiary & 40 & 76.9 \\
Total & $\mathbf{5 2}$ & $\mathbf{1 0 0}$ \\
& & \\
Awareness of the benefits of cashless & Number & Percentage \\
Yes & 40 & 76.9 \\
No & 6 & 11.5 \\
Others & 6 & 11.5 \\
Total & $\mathbf{5 2}$ & $\mathbf{1 0 0}$ \\
& & \\
Cashless policy prevent savings & Number & Percentage \\
Yes & 0 & 0 \\
No & 52 & 100 \\
Total & $\mathbf{5 2}$ & $\mathbf{1 0 0}$ \\
Cashless transactions are expensive & Number & Percentage \\
Yes & 8 & 15.4 \\
No & 44 & 84.6 \\
Total & $\mathbf{5 2}$ & $\mathbf{1 0 0}$ \\
\hline
\end{tabular}

Table 4 titled Security of ATM and POS in a cashless economy starts with the security awareness of a cashless economy. The security of the cashless economy has greatly improved compared to the previous challenges when it was first launched in 2012 [Maitanmi, Awodele, Ogbonna and Osundina, 2013]. ATM was previously porous such that a third party that guessed the password of users can penetrate within three triers without blocking the card. However, technology has improved. Table 4 shows that $39(75 \%)$ believed that the security awareness of the cashless economy has increased users. Similarly, literature has shown that physical transaction has reduced tremendously in Banks. This is shown in table 4, where 20 (38.5\%) respondents consented to this claim. 
Table 4: Security of ATM and POS in a Cashless Economy

\begin{tabular}{lll}
\hline $\begin{array}{l}\text { Security of Cashless Advert Increase } \\
\text { users }\end{array}$ & Number & Percentage \\
\hline Yes & 39 & 75 \\
No & 13 & 25 \\
Total & $\mathbf{5 2}$ & $\mathbf{1 0 0}$ \\
& & \\
The physical transaction has reduced & Number & Percentage \\
due to the cashless economy & & \\
Yes & 20 & 38.5 \\
No & 12 & 23.1 \\
Others & 20 & 38.4 \\
Total & $\mathbf{5 2}$ & $\mathbf{1 0 0}$ \\
& & \\
POS is used for more cash dispenser & Number & Percentage \\
unit than payment unit in Nigeria & & \\
Strongly Agree & 27 & 51.9 \\
Agree & 25 & 48.1 \\
Total & $\mathbf{5 2}$ & $\mathbf{1 0 0}$ \\
ATM users are easily hijacked for force & Number & Percentage \\
withdrawal & & \\
Strongly Agree & 27 & 51.9 \\
Agree & 25 & 48.1 \\
Total & $\mathbf{5 2}$ & $\mathbf{1 0 0}$ \\
Illiteracy increased cashless fraud & Number & Percentage \\
Strongly agree & 39 & 75 \\
Agree & 13 & 25 \\
Total & $\mathbf{5 2}$ & $\mathbf{1 0 0}$ \\
Cashless reduced black money & Number & Percentage \\
Strongly agree & 11 & $\mathbf{7 0 0}$ \\
Agree & 41 & \\
Total & $\mathbf{5 2}$ & \\
\hline
\end{tabular}

The POS is originally developed to help reduce cash handling in a cashless economy, it is most disheartening that the reverse has taken effect in the Nigerian economy where the merchants are no longer in the possession of the POS. Rather, the POS is now being handled by individuals who can afford the registration money through banks, and they are therefore used for businesses around as cash withdrawal points even with the existence of banks with huge percentages to their credits. Table 4 supports this view where the majority of the respondents $27 / 25$ $(100 \%)$ believed that POS is used for more cash withdrawal rather than the payment unit in Nigeria. This is a call to the Nigerian Government to investigate those applying for the procurement of POS and ban those applying for personal gains if the cashless economy would have to be improved like the developed countries. Further hindrances to the cashless economy have been going on for over three years in Nigeria where owners of ATM cards (credit/debit) were hijacked at gunpoint and would be forced to the nearest ATM where they would be requested to withdraw all their earnings.

Many Nigerian have lost billions of Naira to the arm bandits through this method (CBN, 2018). No wonder, table 4 shows that all the respondents $52(100 \%)$ agreed to the fact that ATM users are easily hijacked at gunpoint. This is a call to the Nigerian government and the banking sector to beef up the security camera in various ATM outlets like developed countries, in additional panic alert code should be embedded into the ATM keyboard that works seamlessly as Artificial Intelligence (AI) with the camera and this will usually be ignited if the transaction history of the customers is considered strange for previous transactions. Lastly, on this issue, the CBN should introduce an insurance policy for all financial holders, where insurance companies pay back any amount lost to thefts and other 
accidental discharge. Table 4 supported that a cashless economy has reduced black money where $100 \%$ of the respondents agreed that a cashless economy has reduced corruption in terms of the movement of money to foreign countries this was possible with the introduction of bank verification number (BVN).

\section{Conclusion, Recommendations and Further Research}

The paper has extensively evaluated the security of ATM and POS cashless economy from 2012 to date. We have looked into the awareness level and various security measures and the loopholes involved. It is evidenced that there are still more technological developments needed before Nigerian could be considered among the top 20 economies by the year 2020 and beyond who would drive modernization and development of payment system in line with the Nigerian vision. The following recommendations were made. While the awareness level keeps increasing, the government and the CBN should not relent in their efforts in educating the populace of the advantages involved. The measures to keep users safe and secure should not be kept away from them. For instance, it is still amusing to know that majority of the Nigerians are still in the dark with the fact that rubbers cannot succeed by extorting account holders with POS. Holders of account should willingly release their pin and ATM to robbers knowing fully that the receivers will be picked. The government of Nigeria should strive to fulfill the mandates of the POS to merchandise and unbank areas alone. Further research is needed to find lasting solutions to the issue of armed bandits robbing ATM users.

Acknowledgment: A special appreciation goes to the 2019/2020 Postgraduate Students of Advanced Research, Babcock University, Ilisan Remo, and Ogun State, Nigeria for their contributions to the actualization of this paper.

\section{References}

Ashike, H. (2020). The Cashless policy journey into March 31, 2020, Business Day, 2019. Available at: https://businessday.ng/banking-finance/article/the-cashless-policy-journey-into-march-31-2020/ Accessed Mar. 21, 2020).

Adu, A. C. (2020). Cashless Policy and its Effects on the Nigerian Economy, Eur. J. Business, Econ. Account, 4(2) 81-88.

Adewale, A. A. (2013). The Cashless Nigeria Project: The Subsequent Back Pedaling in the Course of Implementation and the Recent Updates, Glob. Adv. Res. J. Manag. Bus. Stud, 2(1), 37-43.

Akhalumeh, P. B. \& Ohiokah, F. (2011). Nigeria's Cashless Economy: The Imperatives, Int. J. Manag. Bus. Stud, 2, 12-17.

Agu, A. O. \& Agu, S. V. (2020). Cashless policy and the Nigerian economy: A disaggregated approach. International Journal of Humanities Social Sciences and Education, 7(4), 21-30.

Bosupeng, M. (2017). Returns of the Cashless Policy in Nigeria, in Proceedings of Academics World 70th International Conference, Melbourne, Australia, 29-33.

Central Bank of Nigeria. (2018). Economic Report for The First Half of 2018, Available at: www.cbn.gov.ng. Accessed: Jul. 25, 2020.

Central Bank of Nigeria. (2017). Electronic Payments Available fact sheet.

Ezuwore-Obodoekwe, C. N., Eyisi, A., Emengini, S. \& Chukwubuzo, A. F. (2014). A Critical Analysis of Cashless Banking Policy in Nigeria, IOSR J. Bus. Manag, 16(5), 0-42.

Iwedi, M., Igbanibo, D. S. \& Uzo-ahunanya, C. (2018). Effects of Cashless Economy Policy on National Development: Evidence from Nigeria, Journal of Economics and Management Sciences, 1(2), 1-5.

Ikpefan, A. O., Enobong, A., Osuma, G. O., Evbuomwan, G. \& Ndigwe, C. (2018). Electronic Banking and Cashless Policy in Nigeria, Int. J. Civ. Eng. Technol, 9(10) 718-731.

John, N. J., Emmanuel, N. C., Ikechi, K. S. \& Eke, C. K. (2001). Cashless Policy and the Nigerian Payment System Int. J. Innov. Econ. Dev, 5(6), 7-28.

Kasie, E. G. \& Nwaolisa, E. F. (2012). Electronic Retail Payment Systems : User Acceptability and Payment Problems in Nigeria, Oman Chapter Arab. J. Bus. Manag. Rev, 1(9), 111-123.

Muhammad, K. G. (2018). Merits and Demerits of Cashless Policy in Nigeria, Int. J. Law, 1(1), 1-6.

Noone, G. (2018). Sorry, I've only got my card: can the homeless adapt to a cashless society? The Guardian, 2018.

Nwankwo, O. \& Eze, O. R. (2012). Electronic Payment in Cashless Economy of Nigeria: Problems and Prospects, J. Manag. Res, 5(1), 138.

Maitanmi, O., Awodele, O., Ogbonna, C. \& Osundina, S. (2013). Cashless Society: Drive's and Challenges in Nigeria, 
Int. J. Inf. Sci. Tech, 3(2), 1-11. Available at: https://doi.org/10.5121/ijist.2013.3201

Obafemi, T. O. \& Araoye, F. E. (2020). Cashless policy and Nigerian economy: Evaluation of Lagos State experience. IIARD International Journal of Banking and Finance Research, 6(3), 54-62.

Obasanmi, J. O. \& Imasuen, O. F. (2020). Cashless policy in Nigeria: Effects, Challenges and prospects. Journal of Finance and Accounting, 8(1), 18-23.

Omotunde, M., Sunday, T. \& John-Dewole, A. T. (2013). Impact of Cashless Economy in Nigeria, Greener J. Internet, Inf. Commun. Syst, 1(2), 040-043.

Pritchard, J. (2018). The Pros and Cons of Moving to a Cashless Society. The Balance, Available at: https://www.thebalance.com/pros-and-cons-of-moving-to-a-cashless-society-4160702 . Accessed Jul. 25, 2020.

Taiwo, J. N., Oluwafemi, A. K. \& Agwu, E. (2016). Appraisal of Cashless Policy on the Nigerian Financial System, West African J. Ind. Acad. Res, 16(1), 100-109.

Wali, A. F., Wright, L. T. \& Reynolds, P. L. (2014). Cashless System, Users' Perception and Retail Marketing Performance, Bus. Manag. Rev, 5(1), 101-111. 